\title{
REFLEKSJE CHIŃSKICH MATEK NAD SYSTEMEM WARTOŚCI I WZORCÓW SPOŁECZNYCH ZAWARTYCH W BAJKACH: KULTUROWA ANALIZA NARRACYJNA*
}

\author{
CHINESE MOTHERS' REFLECTIONS \\ ON VALUE SYSTEMS AND SOCIAL NORMS ENACTED IN FAIRY TALES: \\ A CULTURAL NARRATIVE ANALYSIS
}

\begin{abstract}
A bstract. This study examined Chinese mothers' views on children's education in China and aimed to identify potential culturally specific perspectives and individual trends. Nine mothers from Beijing were asked to express, in the form of a narrative, their views on the stories that their children watched and read. The interviewees were also asked to assess the delivery, content, values, ideals and model behaviours that characterise Chinese and Western stories for children. The mothers also explained how the aspects of the stories that their children watch and read fit their own expectations and parenting strategies. The data gathered in the study allowed the Authors to create a list of Chinese and Western stories that Chinese children are in contact with, learn what values and model behaviours are expressed in those stories according to the children's mothers, and how these mothers assess the values and model behaviours in the context of their own parental goals. Using
\end{abstract}

Prof. dr hab. ARKADIUSz GUT - Uniwersytet Mikołaja Kopernika w Toruniu, Wydział Filozofii i Nauk Społecznych, Katedra Kognitywistyki; e-mail: arekgut2001@gmail.com. ORCID: https://orcid. org/0000-0002-3983-9474.

Dr JOANNA AFEK - Katolicki Uniwersytet Lubelski Jana Pawła II, Wydział Nauk Humanistycznych, Katedra Sinologii; e-mail: afekjoanna@kul.lublin.pl. ORCID: https://orcid.org/00000002-1135-8097.

Mgr Beata KoŁodzieJ - Katolicki Uniwersytet Lubelski Jana Pawła II, Wydział Nauk Humanistycznych, Katedra Sinologii; e-mail: beba.kolodziej@gmail.com. ORCID: https://orcid.org/00000002-2637-2764.

* Artykuł został przygotowany w ramach projektu badawczego finansowanego przez Narodowe Centrum Nauki, Harmonia (UMO-2014/14/M/HS1/00436) na lata 2015-2018, pt. „Zaangażowanie języka, czynników kulturowo specyficznych i potocznych intuicji w zdolność czytania w umyśle (mindreading) i poznaniu społecznym". 
exploratory factor analysis, the authors identified a number of categories that the Chinese mothers evoked. They discuss the cultural dimensions that characterise the Chinese mothers' perspectives of Chinese and Western stories for children.

Key words: fairy tales; child; educational methods; narratives; Chinese mothers; cultural values; China.

\section{WPROWADZENIE: \\ KONTEKST I STRATEGIA BADAWCZA}

Kwestie dotyczące edukacji dziecięcej w Chinach są ciągle żywo dyskutowanym tematem $\mathrm{w}$ literaturze sinologicznej, opartej w dużej mierze na badaniach socjologicznych i psychologicznych (Chao; Rao, Zhou i Sun; Gut i Afek; Chuang i Yanjie). Można nawet powiedzieć, że chęć zrozumienia istoty edukacji dziecięcej w Kraju Środka oraz intensywnych przemian, jakie tam - w tempie niespotykanym w Europie - zachodzą, jest ważnym składnikiem współcześnie podejmowanych badań międzykulturowych (Fung; Xiao Zhang; Afek i Gut). Z pewnością ma to związek z ciągle żywą debatą na temat skutków socjologicznych i psychologicznych eksperymentu społecznego w postaci „polityki jednego dziecka”. „Polityka jednego dziecka” przełożyła się na istotne zmiany w systemie rodzinnym i społecznym. I choć została w ostatnich latach poluzowana, między innymi od 2015 r. można mieć dwoje dzieci, do czego ponownie zachęca rząd, to jednak realizacja dyrektywy posiadania jednego potomka, wdrażanej w Chinach od 1979 r., wywarła ogromne skutki w myśleniu Chińczyków na temat wychowania dzieci i rozumienia ich potrzeb. $Z$ innej strony, ogromne sukcesy młodego pokolenia chińskiego i nadreprezentowana ich obecność na wielu uczelniach, rodzi pytania o zaszczepiane im wartości, system motywacji oraz wzorce. Przy tym opisywany w literaturze efekt wychowywania w Chinach młodych „księżniczek” i „książąt”, osób z małą odpornością na stres i wyzwania współczesne, jest także efektem polityki jednego dziecka (Falbo; Chao). Unikalność owej sytuacji, jej złożoność w systemie wychowawczym Chin sprawia, że w rozważaniach nad tym zjawiskiem szuka się ciągle strategii badawczych, aby pokazać, jakie wartości i postawy zaszczepia się młodym ludziom w Chinach oraz jak ten system postaw i wartości ma się do modelu zachodniego.

W naszych badaniach, prowadzonych w wyżej zakreślonym obszarze rozważań, interesuje nas odkrycie kulturowo określonych i indywidualnych punktów widzenia, w których wyraz znajdują oceny, postawy matek wycho- 
wujących dzieci w Chinach, formułowane w odniesieniu do określonych dzieł kultury popularnej, jakimi są oglądane przez ich dzieci bajki. W przeprowadzonym badaniu przeprowadzonych $\mathrm{w}$ Chinach poprosiliśmy grupę matek o zaprezentowanie $\mathrm{w}$ formule narracyjnej swoich poglądów na temat oglądanych i czytanych przez ich dzieci baśni i bajek. Rozmówczynie były, z jednej strony, proszone o ocenę różnych aspektów przekazu, treści, wartości, ideałów i postaw przekazywanych przez bajki chińskie i zachodnie, z drugiej zaś ocenę tego, jak oglądane i czytane treści, formy przekazu, wpisują się $\mathrm{w}$ ich oczekiwania, strategie związane $\mathrm{z}$ wychowaniem dzieci. Dzięki zadawanym pytaniom $\mathrm{w}$ odpowiedziach matek otrzymaliśmy bogaty materiał do analizy kulturowej, który pozwala na: (a) zestawienie listy bajek chińskich oraz zachodnich oglądanych przez dzieci chińskie, (b) poznanie, jakie wartości i postawy, w opinii matek, przekazują wymieniane bajki, (c) dowiedzenie sie, na ile przekaz - wartości, historie, bohaterowie - zawarty w tych popularnych tekstach kultury wpisuje się $\mathrm{w}$ strategie wychowawcze obecne w rodzinach chińskich, (d) zobaczenie, jak matki porównują zachodnie i chińskie bajki w odniesieniu do tych postaw i wartości, które chcą zaszczepiać u swoich dzieci.

Trzeba przy tym pamiętać, że wiedza potoczna oraz liczne badania potwierdzają, iż bajki i baśnie, zarówno oglądane przez dzieci, jak i czytane dzieciom, są zasadniczym pasem transmisyjnym dla kluczowych $\mathrm{w}$ danej kulturze wartości oraz postaw indywidualnych i społecznych (Bettelheim; Koutsompou). Podkreśla się, że bajki nie tylko wzmacniają rozwój wyobraźni, pamięci, ale także kształtują moralność i wzorce postępowania kluczowe dla określonej społeczności (McCabe; Zipes).

Od strony strategii badawczej w naszych badaniach matki były proszone o udzielanie nielimitowanych odpowiedzi na zadawane pytania oraz wejście $\mathrm{w}$ dialog z osobą pytającą. Ich odpowiedzi miały formę dłuższych narracji oraz story telling, w których matki opisywały przeżycia dzieci oraz własne odczucia związane z oglądanymi i czytanymi bajkami. Często opisywały konkretne wydarzenia, reakcje lub pytania zadawane przez dzieci w czasie oglądania lub czytania bajek. Tak przygotowane badanie wpisuje się metodologicznie w rodzaj badań narratywnych. Metoda narracyjna stymuluje metapoznanie, refleksyjne odniesienie się do badanej kwestii. Umożliwia również uchwycenie perspektywy, $\mathrm{z}$ jakiej narrator patrzy na pewne zdarzenie z uwzględnieniem własnego doświadczenia. Materiał empiryczny został zebrany $\mathrm{w}$ drodze półstrukturyzowanych wywiadów narracyjnych indywidualnych (Bauer i Gaskell; Jovchelovitch i Bauer). 


\section{BAJKA JAKO NARZĘDZIE EDUKACYJNE ORAZ INSTRUMENT REFLEKSJI \\ W BADANIACH MIĘDZYKULTUROWYCH}

Przed przystąpieniem do analizy materiału zebranego w Chinach warto poruszyć dwie ogólniejsze kwestie. Jedna z nich dotyczy pokazania, jak kluczową rolę w opinii badaczy odgrywa bajka w procesie edukacji dziecięcej. Tutaj przywołamy reprezentatywne poglądy Bruno Bettelheima z pracy $\mathrm{Cu}$ downe i pożyteczne. O znaczeniach $i$ wartościach baśni. W drugiej zaś części niniejszego paragrafu wskażemy na współcześnie prowadzone badania międzykulturowe, w których tematem rozważań jest albo sama bajka, albo takie jwj odczytywanie, które ma ujawniać różnice kulturowe.

\subsection{BAJKA JAKO NARZĘDZIE EDUKACYJNE}

Jedną ze sztandarowych publikacji dotyczących znaczenia baśni i bajek w życiu dziecka jest z pewnością książka Bruno Bettelheima Cudowne i pożyteczne. O znaczeniach $i$ wartościach baśni (1985).

Im bardziej starałem się przeniknąć, dlaczego baśnie z takim powodzeniem wzbogacają życie dziecka, tym wyraźniej zdawałem sobie sprawę, że w sposób znacznie głębszy niż cokolwiek, co napisano, uwzględniają one rzeczywisty stan, w jakim dziecko znajduje się pod względem psychicznym i emocjonalnym. Mówią one o dręczących je konfliktach wewnętrznych tak, że dziecko je nieświadomie rozumie, oraz - nie bagatelizując niezwykle poważnych zmagań wewnętrznych towarzyszących wzrastaniu - podają przykłady zarówno chwilowego, jak trwałego wyjścia z opresji wewnętrznych. (Bettelheim 1: 44)

Z baśni dziecko dowiaduje się, że ludzie są dobrzy i źli, że w życiu trzeba walczyć z poważnymi trudnościami, że w życiu można być samotnym, że zawsze można znaleźć kogoś, kto pomoże i może zostać przyjacielem na całe życie. Co więcej, baśnie i bajki to dzieła sztuki, które są zrozumiałe przez dziecko (Bettelheim 1: 53). W zetknięciu z tym typem materiału dziecko zapoznaje się z kulturą i moralnością:

Baśnie pomagają dziecku w odkrywaniu własnej tożsamości i własnego powołania, wskazując zarazem, jakich potrzebuje ono doświadczeń, aby rozwinąć swój charakter. Tego rodzaju oddziaływania nie wykazuje żaden inny gatunek literacki. (1:68) 
Dziecko przekonuje się, że w życiu trzeba być odważnym (czasami przebiegłym), by osiągnąć swój cel. Nie można także być niedbałym i leniwym, bo konsekwencją takiego postępowania jest zguba (baśń „Trzy małe świnki”). Nie można również wypowiadać życzeń w gniewie, ponieważ mogą spełnić się tak jak w baśni „Janek, mój jeż” czy też „Siedem kruków”. Dopiero dobra wola i wysiłek mogą odwrócić to, co zaszło. Baśnie przedstawiają również proces urzeczywistnienia siebie. Innym wątkiem często występującym w baśni jest motyw dziecka odrzuconego i prześladowanego przez starsze rodzeństwo. Małe dziecko często identyfikuje się z takim „głuptaskiem”, który mimo wszystko i na przekór odnosi w życiu sukces dzięki swojej mądrości i dobroci. Baśnie pokazują również wewnętrzne uniezależnienie się od rodziców. Jest ono konieczne i pożądane. Trwanie w wewnętrznej zależności uniemożliwia osiągnięcie kolejnego stopnia w rozwoju. Każda baśń kończy się szczęśliwie i dzięki temu dziecko osiąga integrację osobowości i harmonię moralną. Baśnie przynoszą słuchaczowi pociechę.

Bettelheim analizuje dokładnie wiele, znanych powszechnie na Zachodzie baśni. Morał z „Jasia i Małgosi” jest, według niego, następujący:

[...] podobnie jak w wielu innych baśniach, rodzeństwo współdziała ze sobą, aby się ocalić i osiąga cel dzięki połączeniu wysiłków. Opowieści tego rodzaju skłaniają dziecko ku przekraczaniu stanu zależności od rodziców i zachęcają je do osiągania dojrzalszej, wyższej fazy rozwojowej, w której doceniłoby także wsparcie, jakie może otrzymać ze strony rówieśników. (2: 17)

Natomiast powszechnie znana baśń „Czerwony Kapturek” (u Bettelheima „Czerwona Czapeczka”) „mówi o namiętnościach ludzkich, o zachłanności oralnej, o agresji i o pragnieniach seksualnych okresu dojrzewania” (2: 42). Dziecko w tej baśni traci dziecięcą niewinność, a zyskuje mądrość dzięki swoim doświadczeniom i powtórnemu narodzeniu (wyjściu z brzucha wilka).

Z kolei baśń „Jack i łodyga fasoli” nie tylko pomaga dorastać dzieciom, ale może też wiele nauczyć rodziców - powinni oni wspierać dzieci w osiąganiu tej dorosłości. Baśnią o dorastaniu, o osiągnięciu dojrzałości seksualnej jest również „Królewna Śnieżka”. Natomiast baśń „Dziewczynka o Złotych Kędziorach” uświadamia dziecku „,[p]o pierwsze - że jest jeszcze dzieckiem, a po drugie - że winno stać się sobą, to znaczy kimś, kto jest różny i od ojca, i od matki, ale zarazem nie jest też tylko dzieckiem swoich rodziców” (Bettelheim 2: 107). Bardzo ważną baśnią jest również „Śpiąca królewna", która ukazuje, że wielkie czyny dokonywane są po latach spoczynku, skupienia i kontemplacji. 
Najstarsza zapisana wersja „Kopciuszka” pochodzi z Chin z IX wieku (Bettelheim 2: 134). Historia Kopciuszka jest jedną z najbardziej znanych. Jak żadna inna ukazuje męczarnie dziecka spowodowane rywalizacją z rodzeństwem. Pokazuje również przechodzenie przez żałobę. Ta baśn to również opowieść o pokonywaniu trudności i osiąganiu dojrzałości, w tym seksualnej. Baśnie, które mówią o narzeczonych zamienionych w zwierzę, pokazują zaś, że miłość nie jest możliwa bez gruntownej zmiany wobec życia seksualnego. Dobrym przykładem jest „Żabi król” czy też „Piękność i Bestia ”.

Te wnioski potwierdzają inne badania. Sześć najbardziej popularnych bajek braci Grimm („Czerwony Kapturek”, „Królewna Śnieżka”, „Jaś i Małgosia”, „Kopciuszek”, „Roszpunka” i „Śpiąca Królewna”) przeanalizowali Nilanjana Sanyal i Manisha Dasgupta. W tych bajkach dziecko może utożsamić się z bohaterami i dowiedzieć, że dzięki mądrości i sprytowi można pokonać każdą trudność (Sanyal i Dasgupta 46). Autorzy ci twierdzą, że „,...] bajki służą przede wszystkim jako tematyczne medium pracy z emocjami dzieci w bezpiecznej, godnej zaufania i bezwarunkowej atmosferze" (47).

Vasile Preda i Elena Cocorada (337) dowodzą, że opowiadanie i słuchanie bajek ma wartość terapeutyczną. Badacze zajmowali się bajkami rumuńskimi, które zawierają uniwersalne wartości, obecne w każdej kulturze. Badaniu poddano 20 dzieci (w wieku 3-10 lat) i 17 rodziców (Preda i Cocorada 340). Uczestniczyli oni w dwóch dwugodzinnych spotkaniach i musieli odrobić dwie prace domowe. Badacze dowiedli, że bajki mają właściwości terapeutyczne, są źródłem porad zarówno dla dzieci, jak i osób dorosłych.

Conny Eisfeld (19) badała adaptacje bajek, rozumiejąc przez to ,przenoszenie historii z jednego medium na drugie przy zachowaniu jednocześnie istoty oryginalnego dzieła". Każda adaptacja jest interpretacją. Adaptacja bajki polega na „wywłaszczeniu i zawłaszczeniu” - oryginalna historia jest wyrwana $\mathrm{z}$ kontekstu i przetworzona przez artystę według jego pomysłu (Eisfeld 21). Wytwórni filmowej Disney często zarzuca się zbyt duże zmiany i spłaszczanie oryginalnych tekstów (Eisfeld 21). Nie ulega jednak wątpliwości, że to Disney, począwszy od 1937 r. i ekranizacji „Królewny Śnieżki” (skończywszy na „Zaplątanych”, zekranizowanych na 50-lecie wywórni) jest największą wytwórnią filmową adaptującą bajki na swoje potrzeby. Mimo że głównymi bohaterkami filmów są zazwyczaj kobiety, to jednak czekają one na swoich męskich wybawców, a w ten sposób utrwalany jest patriarchalizm. Badaczka analizuje bajki (tekst i ekranizacje) „Roszpunkę” i „Czerwonego Kapturka". 


\subsection{BAJKA JAKO NARZĘDZIE W BADANIACH MIĘDZYKULTUROWYCH}

Pisane o dzieciach i dla dzieci w Chinach zapoczątkowali autorzy z okresu Republiki (1911-1949), tacy jak Lu Xun (1881-1936) i jego brat Zhou Zuoren (1885-1967), Mao Dun (1896-1981), Zhang Tianyi (1906- 1985), Bing Xin (1900- 1999), Y. R. Chao (1892-1982) oraz Feng Zikai (18981975), (Jones 2011: 104). W tym czasie przetłumaczono też na język chiński Baśnie braci Grimm (Zhou Zuoren) oraz Alicję w Krainie Czarów (Y.R. Chao). W latach 20. XX wieku zaczęto również produkować zabawki (Jones 122). W latach 30. wiele zabawek importowano z Japonii.

Yehong Zhang i Gerhard Lauer, badając chińskie i niemieckie dzieci dowiedli, że kultura ma duży wpływ na to, jak postrzegane są baśnie. Podkreśla się, co też robią Zhang i Lauer (663-681), że jest stworzeniem tzw. quasieksperymentalnych warunków do badania dziecięcej interpretacji opowieści w codziennym otoczeniu. Do badania wybrano dzieci z Niemiec i Chin i odpowiednio dobrano dwie baśnie - jedną niemiecką i jedną chińską. Dwie wybrane baśnie w przyjętym zamyśle miały być krótkimi, aczkolwiek dynamicznymi opowiadaniami z wyraźnym ukazaniem bohaterów i jednocześnie nieznanymi szerszej publiczności. Najpierw dzieci czytały baśnie, a potem do każdej z nich otrzymywały całą serię stwierdzeń w formie kwestionariusza $z$ prośbą o ich ewaluację. Kluczem sprawy jest sama konstrukcja pytań oraz połączony z tym dobór grupy badawczej. Aby ten proces przeprowadzić, ich autorzy musieli selektywnie sięgnąć do całej grupy badań międzykulturowych i podzielić je na części tematyczne. Pierwszą grupą tematyczną była „postać/bohater”. Drugim obszarem tematycznym była „fabuła”. Trzecim, ostatnim obszarem wyróżnionym przez autorów badania było „miejsce i czas”.

W ramach obszaru oceny bohatera baśni - czyli tego obszaru, w którym liczy się społeczny indywidualizm, odniesienie do innych czy orientacja na zasady społeczne - okazało się, że mali Chińczycy znacznie bardziej, w porównaniu do dzieci niemieckich, akceptowali samodyscyplinę i spełnienie wymagań bohaterów baśni wobec innych. Z kolei postawa aktywna bohatera była znaczenie wyżej oceniana przez czytelników niemieckich niż chińskich. Pasywne poddawanie się biegowi wydarzeń, szybsze dostosowywanie się do rozgrywanych działań i wydarzeń było wyżej ewaluowane przez czytelników chińskich. Ponadto czytelnicy chińscy wykazywali większe zainteresowanie odczytaniem reguł opisywanych w baśniach (Zhang i Lauer 670). Analiza danych pokazuje nie tylko, że modele myślenia oparte na strukturze 
ja niezależnego i ja współzależnego wywierają wpływ na literackie interpretacje, lecz również ilustrują podobieństwa i różnice w bardzo konkretny sposób. Przykład: niemieckie dzieci mają skłonność do oceniania postaci zgodnie $\mathrm{z}$ ich indywidualistyczną motywacją i wewnętrzną przyczynowością, podczas gdy dzieci chińskie preferują społecznie zorientowane zachowania postaci i wolą fabuły, w których przyczynowość jest kolektywistyczna (por. Gut).

Carina Coulacoglou (Exploring the child's personality 41) opracowała i wdrożyła „test bajek” (Fairy Tale Test, FTT), który bada dzieci w wieku 6-12 lat, ich podświadome relacje z bajkami oraz zależność między bajkami a procesami rozwojowymi dzieci. Test zawiera $21 \mathrm{kart}$ z ilustracjami ogólnie znanych bajek („Czerwony Kapturek” oraz „Królewna Śnieżka i Siedmiu Krasnoludków"), na których temat badacz rozmawia z dzieckiem, zadając $\mathrm{mu}$ określone pytania (Exploring the child's personality 42). Na test składa się 29 zmiennych osobowości, które są pogrupowane w pięć kategorii: pragnienia i potrzeby (np. pragnienie dominacji i potrzeba akceptacji), bodźce (np. agresja), relacje z innymi (np. relacja z ojcem), stany emocjonalne (np. złość), ego (np. samoocena). Tym kategoriom badacze przypisują wartości od 1 do 3 (stopień intensywności).

„Test bajek" został przeprowadzony w kilku krajach, m.in. w Chinach (Exploring the child's personality). Badanie chińskie objęło 500 dzieci (235 chłopców i 265 dziewczynek) pogrupowanych według wieku (6-7 lat, 8-9 lat i 10-12 lat) z czterech miast (Pekin, Shenzhen, Han Dan i Dongyjing); wszystkie dzieci znały omawiane bajki (Li i Zhang 224-225). Wnioski z badania są następujące: dzieci chińskie często przejawiają różne rodzaje agresji (m.in. agresję werbalną i odwetową); tak jak w innych kulturach, zachodzi u nich związek między lękiem i depresją i podobnie postrzegają związek z matką (Li i Zhang 237-238). Czynniki odmienne, wynikające z kultury chińskiej, to: sposoby radzenia sobie z agresją, rola ojca $\mathrm{w}$ regulacji wybuchów agresji, jaką wagę przywiązują dzieci do opinii społecznej, ambicja (Li i Zhang 238). Sposoby radzenia sobie z agresją to wycofanie, zaprzeczanie, projekcja, dzielenie, reakcja i racjonalizacja. Matka jest postrzegana jako osoba sroga i karząca. Wśród chińskich dzieci zauważalny jest również kompleks Edypa. 


\section{OPIS BADANIA}

\subsection{Charakterystyka OsÓB BADANYCH}

W badaniu wzięło udział dziewięć matek w wieku 31-38 lat. Rok urodzenia matek według kolejności badania: M1 ${ }^{1}$ : 1981, M2: 1983, M3: 1981, M4: 1985, M5: 1981, M6: [brak danych], M7: 1987, M8: 1978, M9: 1983. Najmłodsza z nich miała 31 lat, a najstarsza 38 (wiek podany na podstawie kwestionariuszy wypełnionych w okresie listopad-grudzień 2016 r.). Badane matki miały tylko jedno dziecko. To zapewne efekt ,polityki jednego dziecka", ponieważ respondentki zostały wychowane przez swoich rodziców w przekonaniu, że posiadanie drugiego dziecka może mieć więcej negatywnych niż pozytywnych skutków.

W związku z tym matki, z tak zakorzenionymi przekonaniami, urodziły tylko jedno dziecko. Podczas wstępnych rozmów prowadzonych przed rozpoczęciem właściwych wywiadów opowiadały, jak trudne i kłopotliwe jest posiadanie drugiego dziecka, przedstawiały bardzo wysokie koszty związane z utrzymaniem, edukacją i przyszłym życiem kolejnego potomka, a także potwierdzały przekonanie, że lepiej mieć jedno dziecko, któremu można zapewnić wszystko, niż dwoje, które wychowa się połowicznie i nigdy w pełni nie zaspokoi się potrzeb obojga.

Żadna $\mathrm{z}$ badanych nie była ani wdową, ani rozwódką - wszystkie były mężatkami. Każda z nich żyła i pracowała w Pekinie, głównie w dzielnicy Shunyi 顺义区 ${ }^{2}$, zlokalizowanej na obrzeżach stolicy. Ich życie ograniczało się przede wszystkim do tego regionu, ponieważ nie czuły potrzeby odwiedzania ścisłego centrum miasta czy miejsc bardziej atrakcyjnych turystycznie. Kobiety pracowały m.in. w firmach medialnych oraz $\mathrm{w}$ oświacie, gdzie zajmowały różne stanowiska. Niektóre z nich znały się wcześniej, ponieważ pracowały w jednej szkole podstawowej, gdzie uczyły języka angielskiego. Matki były bardzo zżyte ze swoimi dziećmi. Szczególnie widoczne było to u jednej z nich. Podczas wywiadu osoba go przeprowadzająca siedziała razem $\mathrm{z}$ tą respondentką $\mathrm{w}$ jednym pokoju, a jej dziecko bawiło się $\mathrm{z}$ innym dzieckiem w drugim. Nagle jedno z dzieci zaczęło płakać, a matka od razu przerwała rozmowę, pytając: „Kto to płacze?”. Chwilę nasłuchiwała, aż wre-

\footnotetext{
${ }^{1}$ Matkom losowo przydzielono kolejne numery od 1 do 9 . Respondentki zostały zatem opisane jako M1 - M9.

${ }^{2}$ Dzielnica Shunyi (顺义区, w tradycyjnym chińskim: 順義區, pinyin: Shunyi Qu) jest regionem administracyjnym miasta Pekin. W 2014 r. mieszkało tam około 983 tys. mieszkańców. Na obrzeżach dzielnicy znajduje się Międzynarodowe Lotnisko w Pekinie.
} 
szcie doszła do wniosku, że to nie jej dziecko i jak gdyby nigdy nic kontynuowała swoją wypowiedź. Była jednak czujna przez cały czas trwania badania.

Tabela 1. Charakterystyka matek uczestniczących w badaniu

\begin{tabular}{|c|c|c|c|c|c|c|}
\hline MATKA & PSEUdONIM & STAN CYWILNY & WIEK & $\begin{array}{c}\text { MIEJSCE } \\
\text { ZAMIESZKANIA }\end{array}$ & $\begin{array}{c}\text { OBECNA PRACA / } \\
\text { ZAWÓD }\end{array}$ & LICZBA DZIECI / PŁEĆ / WIEK \\
\hline 1 & Matka 1 & Mężatka & 35 & Pekin & Firma Zespa Media & 1 / chłopiec / $4 \mathrm{l} .9 \mathrm{~m}$. \\
\hline 2 & Matka 2 & Mężatka & 33 & Pekin & Nauczycielka & 1 / chłopiec / 3 I. $11 \mathrm{~m}$. \\
\hline 3 & Matka 3 & Mężatka & 35 & Pekin & Nauczycielka & 1 / dziewczynka / $4 \mathrm{l} .9 \mathrm{~m}$. \\
\hline 4 & Matka 4 & Mężatka & 31 & Pekin & Nauczycielka & 1 / dziewczynka / $4 \mathrm{l} .3 \mathrm{~m}$. \\
\hline 5 & Matka 5 & Mężatka & 35 & Pekin & Nauczycielka & 1/ chłopiec / $61.1 \mathrm{~m}$. \\
\hline 6 & Matka 6 & Mężatka & ? & Pekin & Nauczycielka & 1/ chłopiec / 4 I. \\
\hline 7 & Matka 7 & Mężatka & 29 & Pekin & Nauczycielka & $1 /$ chłopiec / $21.8 \mathrm{~m}$. \\
\hline 8 & Matka 8 & Mężatka & 38 & Pekin & Nauczycielka & 1 / dziewczynka / 5 I. \\
\hline 9 & Matka 9 & Mężatka & 33 & Pekin & Nauczycielka & 1/ dziewczynka / 41.7 m. \\
\hline
\end{tabular}

\subsection{OPIS PYTAŃ}

Oto lista pytań zadanych matkom podczas wywiadu:

1. Jakie filmy lub bajki chińskie ogląda Twoje dziecko? Proszę, abyś je wymieniła oraz powiedziała, o czym są te filmy lub bajki.

2. Jak sądzisz, jakie postawy społeczne przekazują oglądane przez Twoje dziecko bajki lub filmy. Proszę przedstaw je pokrótce.

3. Czy akceptujesz treści, motywy, postacie przedstawiane w oglądanych przez dziecko bajkach lub filmach? Jeśli tak, to dlaczego - jeśli nie, to dlaczego.

4. Jakie chińskie bajki czytasz swojemu dziecku? Proszę wymień i coś o nich powiedz.

5. Czy obok bajek lub filmów chińskich Twoje dziecko ogląda bajki zagraniczne? Jeśli tak, powiedz jakie.

6. Czy obok bajek chińskich czytasz swojemu dziecku bajki zagraniczne? Jeśli tak, powiedz jakie.

7. Jakie są, Twoim zdaniem, główne różnice między bajkami lub filmami chińskimi a zagranicznymi? Proszę powiedz, które bajki lub filmy preferujesz, aby Twoje dziecko oglądało i dlaczego. 
Badanie zostało przeprowadzone $\mathrm{w}$ okresie trzech miesięcy od września do grudnia 2017 r. Jak wspomniano, wywiady przebiegały w bardzo miłej, spokojnej i bezstresowej atmosferze. Początkowo nastawienie matek do wywiadów było różne. Niektóre $\mathrm{z}$ nich z ogromną ciekawością podchodziły do tego zagadnienia - zachowywały się tak, jakby brały udział w wielkim naukowym przedsięwzięciu. Inne najpierw dość nieufnie i niepewnie odpowiadały na pytania, ale zwykle już przy pytaniu nr 2 rozluźniały się i bez żadnych oporów opowiadały o swoich prywatnych sprawach, o stylu w jakim wychowują swoje dzieci oraz o różnych wydarzeniach $\mathrm{z}$ ich codziennego życia. Kilka respondentek odchodziło czasem od głównego tematu, przez co czas wywiadu znacznie się wydłużał. W takiej sytuacji nie przerywano im, ponieważ dzięki temu mogły powiedzieć wszystko to, co chciały.

Matki czuły się swobodnie i nie traktowały osoby zadającej pytania jak śledczego, który zadaje konkretne pytania i oczekuje konkretnych odpowiedzi, ale osobę pragnącą poznać ich punkt widzenia, przeżycia, emocje. Możliwe, że była to ich pierwsza taka okazja, aby móc porozmawiać o swoich sprawach rodzinnych $\mathrm{z}$ osobą z zupełnie innego kręgu kulturowego osoba przeprowadzająca wywiad była Polką. Można było odnieść wrażenia, że to właśnie dzięki temu, że była ona waiguo ren 外国人, czyli obcokrajowcem, matki mówiły z większą szczerością.

\subsection{OPIS I CHARAKTERYSTYKA TREŚCIOWA BAJEK WYMIENIONYCH PRZEZ MATKI}

Bajką najczęściej wymienianą przez matki (siedem na dziewięć) jest „Polowanie na misia” (熊出没 Xiong chumo, ang. „Boonie Bears”). „Polowanie na misia" to chińska kreskówka opowiadająca o dwóch niedźwiedziach: Seniorze (熊大 Xiong $d a$ ) i Juniorze (熊二 Xiong er), które strzegą lasu przed Łysym Osiłkiem (光头强 Guangtou qiang), chcącym wyciąć drzewa dla dużego zarobku. Po raz pierwszy kreskówkę wyemitowano w styczniu 2012 r., a do tej pory wyprodukowano ponad dwieście trzynastominutowych odcinków, powstały także filmy długometrażowe opowiadające o przygodach niedźwiedzi.

Pierwszy odcinek, pt. „Nowy sąsiad” (新邻居 Xinlinju) pokazuje zabawę niedźwiedzi, którą przerywa przyjazd człowieka - Łysego Osiłka. Ma on za zadanie wycinać drzewa dla pieniędzy (co jest dyskredytowane). Jeden z niedźwiedzi, Junior, zostaje przekupiony jedzeniem, Senior natomiast nie daje się przekupić i bije Łysego Osiłka, który ścina kolejne drzewo. Na filmie jest pokazany sam moment uderzenia, jak też niszczenie piłą samochodu 
człowieka i strzelanie do niedźwiedzia. Człowiek zostaje pokonany i musi uciekać z lasu. Bohaterowie kreskówki posługują się „dorosłym” językiem, pada nawet chińskie przysłowie (chengyu) zawierające słowo oznaczające „bezdomnego” (wu jia ke gui 无家可归).

Kolejną chińską bajką, którą oglądają dzieci w Chinach, jest „Miła kózka i wielki wilk” (喜羊羊与灰太狼 Xiyangyang yu huitailang, ang. „Pleasant Goat and Big Big Wolf"). Bajka jest wspominana przez trzy matki. Jest to kreskówka emitowana od 2005 r. Stała się bardzo popularna w Chinach i całej Azji, a Disney wykupił prawo do emisji tej kreskówki (przez co dotarła do 52 krajów na świecie). Opowiada ona o życiu małych kózek i o wilku, który chce je zjeść. Początkowo powstało 530 odcinków tej bajki, później kolejnych 480; powstały także długometrażowe filmy o przygodach bohaterów. Kreskówka zdobyła też wiele nagród przemysłu filmowego.

Pierwszy trzynastominutowy odcinek, pt. „Przyszedł wilk” (狼来了 Lang laile), przywołuje historię z przeszłości, kiedy to wilk dostał się podstępem do wioski kóz otoczonej żelaznym płotem (schudł i przecisnął się przez pręty), ale zjadł zatrutą atrapę kózki i zmarł. Po latach kolejny wilk chce się dostać do środka, ale mu się nie udaje, ponieważ kózki są mądre i sprytne, nie dają się łatwo oszukać. W tym odcinku kózki kończą szkołę i zaczynają wakacje, a szef wioski daje im takie rady: „w wakacje słuchać rodziców”, „odrabiać wakacyjną pracę domową”, „przestrzegać zasad bezpieczeństwa na drodze”, „w czasie zabawy nie biegać zbyt daleko” oraz „zawsze uciekać przed wilkiem”. Na ekranie pojawia się napis „wilk” (znak oraz transkrypcja pinyin). Bajka ma niewątpliwie charakter edukacyjny, ale utrwala też stereotyp złego wilka.

Jedna z matek krytykuje kreskówkę za nieprawdziwy przekaz - wilk zostaje kilkakrotnie zabity, ale później udaje mu się odżyć, co może wprowadzać dzieci w błąd.

Popularną bajką jest kreskówka „Latający superbohaterowie” (超级飞侠 Chaoji fei xia, ang. „Super Wings”). Mówią o niej trzy matki, z którymi przeprowadzano wywiad. Jest to koreańsko-amerykańsko-chińska kooprodukcja, której emisja rozpoczęła się w Chinach w 2015 r. Dwa sezony kreskówki to ponad sto odcinków, każdy po około 12 minut. W każdym odcinku czerwony samolot Le Di (乐迪 Le Di, ang. Jett), czyli główny bohater, ma za zadanie zawieźć przesyłkę do jakiegoś miasta, regionu lub kraju, które są skrótowo prezentowane odbiorcom. Gdy napotyka na problemy, pomaga mu je rozwiązać jeden z przyjaciół samolotów. Cechą charakterystyczną każdego odcinka jest „słowo-klucz”. Dzięki temu dzieci z każ- 
dego odcinka mogą nauczyć się nowych słów z całego świata, np. po włosku, grecku, angielsku, arabsku, portugalsku, japońsku itd.

W pierwszym odcinku, zatytuowanym „Razem puśćmy latawiec” (一起放 风笔 Yiqi fang fengzheng), bohater odwiedza Himalaje i mieszkające tam dzieci, którym zawozi latawiec. Słowem-kluczem jest Namaste w języku hindi oznaczające „Cześć!”.

Jedna $\mathrm{z}$ matek chwali bajkę za uczenie pomagania innym i współpracy.

Inne bajki wymieniane przez matki to: „Chrapanie” (呼噜 Hulu), „Bracia z tykwy” (葫芦兄弟 Hulu xiongdi, ang. „Calabash Brothers”), „Czarny Kot Detektyw” (黑猫警长 Hei mao jing zhang, ang. ,Black Cat Detective”), „Narodzenie” (诞生 Dan sheng), „Chińskie wspomnienia”（中国记忆 Zhangguo jiyi), „Tata inżynier” (工程师爸爸 Gongchangshi baba), „Świnka Bohater” (猪猪侠 Zhu zhi xia, ang. „GG Bond”), „Wielkogłowy syn i małogłowy tata” (大头儿子和小头爸爸 Da tou er zi xiao tou baba), „Małpi Król powoduje spustoszenie w niebie" (孙悟空大闹天宫 Sunwukong da nao tiangong), „Mała kijanka szuka mamy” (小蝌蚪找妈妈 Xiao kedou zhao mama). W większości są to klasyczne opowiadania chińskie, na których podstawie stworzono kreskówki.

Zagraniczną bajką oglądaną przez chińskie dzieci (cztery na dziewięć) jest „Świnka Peppa” (粉紅豬小妹 Fenhong zhu xiao mei, ang. „Peppa Pig”). Jest to brytyjski serial animowany dla dzieci w wieku przedszkolnym, opowiadający o przygodach Świnki, jej rodziny i zwierzęcych przyjaciół. Pierwsza 52-odcinkowa seria została wyemitowana w 2004 r., potem pojawiły się następne. Serial jest oglądany przez dzieci niemal na całym świecie (180 obszarów). Każdy odcinek trwa około pięciu minut.

W odcinku zatytułowanym „Ogrodnictwo” Świnka Peppa wraz ze swym bratem odwiedzają dziadków. Dziadek tłumaczy i pokazuje wnuczętom, że rośliny wyrastają z nasion - Peppa sadzi ziarenko truskawki, a podczas następnych odwiedzin zjada $z$ bratem dojrzałe owoce. Bajka ma niewątpliwie walory edukacyjne. W serialu mama jest mądrzejsza od taty, a siostra od brata.

W Chinach „Świnka Peppa” spotkała się z bardzo pozytywnym odbiorem - matki chwalą pokazywanie harmonijnego życia rodzinnego, przyjazne traktowanie dzieci przez rodziców, udział ojca w wychowaniu dzieci. Jedyny zarzut to zbyt piskliwy głos Świnki.

Chińskie dzieci oglądają też filmy zagraniczne, które produkuje np. Disney czy Pixar. Są to takie produkcje, jak: „Król Lew” (2004), „Kung Fu Panda” (2008), „Zaplątani” (2010), „Kraina Lodu” (2013), „Minionki” (2015), „W głowie się nie mieści” (2015), „Sekretne życie zwierzaków domowych” (2016), „Vaiana: skarb oceanu” (2016) , „Zwierzogród” (2016). 
Z chińskich książek czytane są zazwyczaj klasyczne pozycje, jedna z matek wspomina nawet o „San zijing” (三字经 Sanzijing, ang. ,, The Three Character Classic"), klasycznej pozycji z kanonu konfucjańskiego z XIII wieku, służącej do nauki pisma i wartości konfucjańskich przez chińskie dzieci przez setki lat. Kolejną, podobną książką jest „Di zigui” (弟子规 Dizigui, ang. „Standards for being a Good Pupil and Child”), która powstała w czasie panowania dynastii Qing (1644-1911) i również uczy, jak być dobrym dzieckiem i uczniem w świetle wartości konfucjańskich. Matka mówi, że dziecko uczy się tych lektur w szkole, a w domu recytuje (czyli zachowany jest tu tradycyjny model nauczania na pamięć). Matki czytają głównie klasyczne baśnie chińskie, a z pozycji zagranicznych też klasykę (baśnie Andersena lub Grimma) albo książki obrazkowe.

\section{ANALIZA KATEGORIALNA WYPOWIEDZI MATEK}

Na podstawie pytań i odpowiedzi matek zostało wyróżnionych jedenaście kategorii: wartości społeczne, ochrona środowiska, ochrona i pomoc słabszym, sprawiedliwość, odwaga, wartości edukacyjne, dobro, zabawa, własne zdanie, przemoc i zło oraz brak sensu.

Kategorią, która pojawia się najczęściej, bo aż czterdzieści jeden razy (w każdym wywiadzie, u dziewięciu matek) jest „przemoc i zło”. Bajki, które pokazują agresywne zachowania, są krytykowane. Matka 2 mówi: „Chińskie filmy, kreskówki, np. «Polowanie na misia» [...] przekazuje trochę złych rzeczy, np. w tej bajce często się biją, używają broni, strzelają do tych niedźwiedzi lub atakują piłą innych. To daje dzieciom efekt przemocy, nie jest to dobre”. A Matka 6: „Uważam, że zawartość «Łysego Siłacza» jest zła, pełna przemocy. Myślę, że nie tylko zachowania są agresywne, ale i język. To agresywne zachowanie to nie tylko to, jak Łysy Siłacz zawsze bije Niedźwiedzia Seniora i Niedźwiedzia Juniora. Myślę, że moje dziecko, jak tylko ktoś inny stanie naprzeciwko niego, to on zawsze chce bić innych. Jeśli chodzi o agresywny język, to szef Łysego Siłacza, szef Li, zawsze jak do niego dzwoni, to się drze, później moje dziecko się tego uczy, (podpiera się rękami na biodrach i krzyczy): «Jestem szefem Li, coś tam coś tam... słuchaj tego, co do ciebie mówię!». Więc uważam, że to jest złe". A dalej: „Tego typu pozytywy, jak w «Łysym Siłaczu», mogę zaakceptować, ale zawarta $\mathrm{w}$ nim agresja powinna zostać ponownie zredukowana. Ten «Łysy Siłacz» był już jednak poprawiany, pierwotnie był jeszcze bardziej przepełniony przemocą. Uważam, że powinien zostać ponownie zmieniony. 
Takie jak «Kung Fu Panda» lub inne kreskówki są dobre, przekazują sprawiedliwość, są ok według mnie".

Drugą, najczęściej pojawiającą się kategorią są „wartości edukacyjne” bajek. Ta kategoria pojawia się dwadzieścia sześć razy w ośmiu wywiadach. Bajki mające walory edukacyjne są chwalone. Matka 1 mówi: „Jest jeszcze jedna, która się nazywa «Dora odkrywca». Dziewczynka szuka różnych rzeczy. Musi przejść przez 3 miejsca. Można się z tego nauczyć bardzo wielu angielskich słówek. Kiedy nauczyciel uczy, to można zapomnieć, ale jak się często ogląda to samemu, można się uczyć”, a także: „[...] Główna różnica jest taka, że chińskie kreskówki są odpowiednie tylko dla małych dzieci. Zagraniczne natomiast, ja sama chciałabym wszystkie obejrzeć. Rodzice też mogą się czegoś nauczyć. Na przykład «Ultraman», ja też lubię go oglądać, bardzo pasuje głowie rodziny. Również «Dora», niezwykle radosna, opowiada o Wielkanocy, Bożym Narodzeniu... lub dociera do jakiegoś kraju, a tam przyjmuje cię król, jest jakaś ceremonia, to jest bardzo interesujące!". Matka 8 zaś twierdzi: „Kochająca grać na gitarce świnka Peppa też ma aspekty, których można się nauczyć. Przechodząc przez przygodowe historie, uczy się angielskich słówek".

Kolejną wartością jest „dobro”. Jeśli bajka pokazuje szczęście lub harmonię, to jest odbierana pozytywnie. Ta kategoria pojawia się dwadzieścia jeden razy w ośmiu wywiadach. Matka 3 mówi: „Mówiłaś o oglądaniu filmów... ostatnio oglądałyśmy «Vaianę: Skarb oceanu». One poruszają kwestie odwagi, nieustępliwej wytrwałości. Jeżeli małe dziecko to ogląda, to jest to dla niego dobre. Co więcej, moja córka ostatnio uwielbia oglądać «Krainę Lodu». Elsa i Anna, piękne, niezwykle piękne, odważne. Anna poszła szukać Elsy, to jest to też bardzo dobre, takie postacie mogę zaakceptować". A Matka 5 tak wypowiada się o „Śwince Peppie”: „Naprawdę tak uważam, naprawdę, więc uważam, że dzieci kochają oglądać ten film o szczęśliwej rodzinie, bo one bardzo pragną takiego życia."

Czwartą kategorią są „obyczaje”, rozumiane jako kultura osobista i odpowiednie maniery. Ta kategoria pojawia się piętnaście razy w siedmiu wywiadach. Matka 7 mówi: „Uważam, że głównie może przekazać chęć pomocy innym lub siłę, jaka drzemie w grupie” oraz „To też jest historia o tym, jak między przyjaciółmi jest wzajemna pomoc, opowiada o przyjaźni”. A mama 9 dodaje: „Te filmy i kreskówki przekazują społeczną sprawiedliwość i maniery, dobre postawy społeczne".

Piąta kategoria to „ochrona środowiska”, która pojawia się dziewięć razy w czterech wywiadach. Temat zatrucia środowiska jest obecny w chińskich mediach, ponieważ jest to ogromny problem współczesnych Chin. Matka 2 
mówi: „Chińskie filmy, kreskówki, np. «Polowanie na misia», jakie przekazuje on postawy społeczne... Po pierwsze mówi dziecku, że trzeba chronić lasy, strzec środowisko”. Matka 7 twierdzi: „Niedźwiedź Senior, Niedźwiedź Junior - to, co przekazuje, to pewne troszczenie się o środowisko, ochrona lasu, harmonijny kontakt ludzi i zwierząt".

Kategoria „ochrona i pomoc słabszym” pojawia się dziewięć razy w czterech wywiadach. Matka 2 mówi: „Syn lubi oglądać «UltramanTiga». Jest to silny człowiek, który walczy z potworami i chroni ludzi na ziemi”. Słowa Mamy 7: „Uważam, że głównie może przekazać chęć pomocy innym, lub siłę, jaka drzemie w grupie".

Kolejną kategorią jest „odwaga”. Występuje osiem razy w trzech wywiadach. Matka 3 mówi: „Mówiłaś o oglądaniu filmów... ostatnio oglądałyśmy "Vaianę: Skarb oceanu». One poruszają kwestie odwagi, nieustępliwej wytrwałości. Jeżeli małe dziecko to ogląda, to jest to dla niego dobre". A także: „Wszystkie zagraniczne filmy mają szczególnie jasno sprecyzowany temat, np. przygoda, odwaga, wytrwałość, tego jest całkiem sporo". Natomaist Matka 8: „Moje dziecko lubi oglądać bajki Dinseya, np. «Zaplątani», «Dzwoneczek», «Luna Flower», «Kraina Lodu», albo kreskówki, jak uwielbiająca grać na gitarce świnka Peppa przypomina film Dinseya. Zasadniczo wszystkie nawiązują do pokonywania trudności oraz do tego, jak ostatecznie poznać prawdę, dobro, piękno itp.”.

Wyróżniona została również kategoria „sprawiedliwość”, która pojawia się sześć razy w trzech wywiadach. Matka 1 twierdzi, że jej dziecko „lubi oglądać dwa rodzaje, pierwszy $z$ nich to takie radosne, a drugi: jak sprawiedliwość tryumfuje nad złem. [...] Drugi rodzaj to taki, w których ludzie z poczuciem sprawiedliwości dzięki swojej sile pokonują wrogów, ocalają ziemię”. Matka 6: „Takie jak «Kung Fu Panda» lub inne kreskówki są dobre, przekazują sprawiedliwość, są ok według mnie".

"Własne zdanie" to kolejna kategoria, która pojawia się sześć razy w dwóch wywiadach. Matka $6 \mathrm{w}$ ten sposób porównuje książki chińskie i zagraniczne: „Chińskie używają ogromnej liczby znaków do mówienia, a zagraniczne używają ilustracji, więc myślę, że zagraniczne są lepsze. Pozwalają ci mieć własne zdanie”. Oraz: „Zagraniczne nie dają ci stereotypowej odpowiedzi, ale pozwalają ci samemu powiedzieć, co jest dobre. To, co ty mówisz, jest dobre; to, co on mówi, też jest dobre. Według mnie to, co mówisz jest bardzo dobre. Po prostu zagraniczne pozwalają ci mieć swoją własną opinię, co jest bardzo dobre, więc potem mogę kupić dużo zagranicznych książek". 
Przedostatnią kategorią jest „brak sensu”. Pojawia się ona pięć razy w trzech wywiadach. Matka 1 mówi: „Uważam, że zagraniczne kreskówki nie są złe, ponieważ zawierają naukę dla każdego, ale niektóre kreskówki nie mają zbyt dużego sensu, jak np. koreański «Backkom» (Pechowy miś), który nie ma sensu”.

Ostatnia kategoria to „zabawa”, która występuje cztery razy w czterech wywiadach. Wydawałoby się, że jest to główna wartość, dla której czyta się książki i ogląda bajki, ale tak nie jest. Ta kategoria pojawia się najrzadziej. Matka 8 mówi: „Jeżeli bajka daje radość, użyteczną motywację, to nieważne, czy jest chińska, czy zagraniczna".

Tabela 2. Wartości i antywartości obecne w bajkach przywoływane przez Matki

\begin{tabular}{|c|c|c|}
\hline WartoścI & LICZBA WYWIAdóW & CAŁKOWITA LICZBA \\
\hline Przemocizło (agresja) & 9 & 41 \\
\hline Wartości edukacyjne & 8 & 26 \\
\hline Dobro (szczęście, harmonia) & 8 & 21 \\
\hline Obyczaje (kultura, maniery) & 7 & 15 \\
\hline Ochrona środowiska & 4 & 9 \\
\hline Ochrona i pomoc słabszym & 4 & 9 \\
\hline Odwaga & 3 & 6 \\
\hline Sprawiedliwość & 3 & 6 \\
\hline Własne zdanie & 2 & 5 \\
\hline Brak sensu & 3 & 4 \\
\hline Zabawa (radość) & 4 & \\
\hline
\end{tabular}

\section{HARMONIA: POSZUKIWANIE KULTUROWEGO LEJTMOTYWU}

W wypowiedziach matek, niezależnie od konkretnego pytania dotyczącego oglądanych przez ich dzieci bajek, pojawia się wspólny lejtmotyw, który pokazuje sposób ujmowania i osadzania sfery moralnej, edukacyjnej, współżycia społecznego oraz szczęścia w określone ramy kulturowe, w których żyją i funkcjonują nasze respondentki. Tym lejtmotywem jest kategoria harmonii. Instruktywne bowiem jest to, że kiedy matki mówią np., że dzięki bajkom dzieci uczą się szacunku dla zwierząt i świata przyrody, to pod- 
kreślają, w rozwinięciu do tej kwestii, wprost lub nie wprost, że dzieci uczą się budowania harmonijnego współżycia między światem ludzi i zwierząt (Matka 7). Z kolei, kiedy mówią o tym, jakich postaw społecznych uczą bajki, podkreślają jednocześnie, że bajki uczą trwania w harmonii. Przywołanie idei harmonii pojawia się, w równym stopniu, gdy matki mówią o relacji dziecka do natury, jak i dziecka do innych osób (tj. rodziców, rówieśników itd.) (Matka 6,7). W wypowiedzi Matki 5, na której chcemy zatrzymać się dłużej, ujawnia się zasadniczo głębszy pokład, w jakim rozmówczynie umieszczają mówienie o harmonii.

Uważam, że dzieci, wliczając mnie (rodziców), po obejrzeniu tej różowej świnki myślą, że ich cała rodzina jest szczególnie harmonijna, jej tata i mama i młodszy brat. [...] Uważam, że ta świnka daje ludziom dokładnie takie odczucie. Po obejrzeniu czułam, że ich rodzina jest niezwykle szczęśliwa, że tata i mama chcą się bawić razem z dziećmi. (Matka 5)

Widać tutaj, po pierwsze, że matka mówi o symbiozie rodzinnej związanej z obecnością rodziców z dzieckiem, ich asystowaniu we wzrastaniu i wychowaniu ich córki; po drugie, ten rodzaj harmonii jest powiązany z dobrostanem (tj. well-being) rodziny; po trzecie, $\mathrm{z}$ odczuwaniem szczęścia i satysfakcji z życia rodzinnego i wychowania potomstwa. Widać wyraźnie, że harmonia to stan, do którego się dąży, a co więcej - jest ona jednocześnie nie tylko warunkiem braku konfliktu, gwarantem spokoju i komfortu, ale także warunkiem odczuwania szczęścia i radości.

Spróbujmy zatem umieścić ten wątek w szerszym kontekście. Wydaje się, że w tych wypowiedziach ujawnia się kluczowy komponent myślenia w kulturze chińskiej, który koncentruje się wokół kategorii harmonii. L. Feng i D. Newton, podkreślają, że konfucjańskie pojęcie „harmonii” (he xie 和谐) przenika ciągle chińską kulturę w warstwie pewnego ideału i jest szczególnie obecne w systemie moralnym i edukacyjnym (341-342). Kluczową sprawą jest to, że harmonię traktuje się jako cel w życiu społecznym, rodzinnym, ale także osobistym. W tym sensie nie sprowadza się tej naczelnej wartości wyłączenie do zasady negatywnej, tj. unikania konfliktu, lecz traktuje się ją jako motyw do współdziałania, wraz z dawaniem od siebie tyle, ile proporcjonalnie bierze się od innych - w tym także od świata natury. Co więcej, idąc tropem Konfucjusza i jego stwierdzenia zawartego we fragmencie Analektów $13,23^{3}$, można powiedzieć, że człowiek prawy powinien dążyć do

\footnotetext{
${ }^{3}$ Mistrz powiedział: „Człowiek moralnie doskonały (junzi 君子) utrzymuje harmonijne stosunki [z ludźmi], [ale ich] nie naśladuje. Prostak (xiaoren 小人) naśladuje [innych], ale nie utrzymuje z nimi harmonijnych stosunków” (Konfucjusz, Analekta 13, 23; pol. Pejda 144).
} 
harmonii z innymi i jednocześnie powinien unikać postawy biernej i chłodnej (tj. nienasyconej uczuciami). Postawa bierna i chłodna cechuje człowieka małego, czyli kogoś na przeciwnym biegunie w stosunku do prawego człowieka. W dążeniu do harmonii nie chodzi więc jedynie o bycie bezkonfliktowym obserwatorem, lecz o zaangażowanie, którego składnikiem ma być działanie, i to działanie uczuciowo zabarwione. Moralność w tradycji Konfucjusza, jak podkreśla Seok, wymaga emocjonalnego zaangażowania, nie jest ona bowiem napędzana wyłącznie spełnianiem intelektualnych zasad (Seok). Kluczowe dla budowania harmonii jest uczuciowo zakotwiczone wejście w sytuację społeczną i rodziną. Pisze o tym wyraźnie Konfucjusz:

Kiedy człowiek moralnie doskonały (junzi 君子) wypełnia obowiązki wobec bliskich, staje się to bodźcem dla ludu, aby ten [praktykował relacje] (ren 仁); jeśli nie porzuca dawnych przyjaciół, ludzie będą troszczyć się o siebie nawzajem. (Konfucjusz 8,2; Pejda 86)

Obecność w grupie (kraj, praca, rodzina) zgodnie z zasadą harmonii wymaga przejścia z pozycji obserwatora do pozycji aktora. Trzeba odejść od postawy naśladowania i zająć pozycję przywiązania, a w ramach niej rozwijać więź z członkami danej grupy, a ta więź nie pozwala mu ani na bierność, ani na oddanie swojej roli w inne ręce. Co ważne, współcześnie prowadzone badania potwierdzają, że w świadomości potocznej u Chińczyków zachodzi ciągle istotne powiązanie między harmonią na różnych poziomach (politycznym, społecznym, zawodowym, rodzinnym) a odczuwaniem szczęścia. Jak pokazują badania Po-Keung Ip, opublikowane w artykule „Harmony as Happieness? Social Harmony in Two Chinese Societies", dążenie do harmonii jest powiązane z budowaniem szczęśliwego społeczeństwa. Nakładanie się tych dwóch kwestii jest $\mathrm{w}$ chińskim modelu myślenia niezmiernie symptomatyczne.

Przypomnienie tej kulturowej specyfiki odsłania racje zawarte w wypowiedziach matek, pozwala nam także lepiej zrozumieć głos jednej z nich, kiedy w dłuższej wypowiedzi, odnoszącej się do jej osobistej historii, wskazuje na przemiany, które stają na przeszkodzie w osiągnięciu domowej harmonii. Jak można zauważyć, istotne jest dla niej, że harmonia jest kluczowa dla zrealizowania sytuacji dobrostanu i szczęścia w rodzinie. Matka, w nawiązaniu do bajki „Świnka Peppa”, mówiąc wcześniej o domowej harmonii, która jest tam obecna (co podkreśliliśmy wyżej w cytacie Matki 5), mówi:

Myślę, że nasza rodzina bardzo pragnie takiego życia, ponieważ w chińskich domostwach ojcowie nie za bardzo zajmują się dziećmi, dzieci są dane matkom 
do wychowania. Wszystkie chińskie rodziny są takie. Możliwe, że w zagranicznych rodzinach ojcowie i matki razem je wychowują, mogą jeszcze wychować wiele dzieci, mogą bawić się z nimi w domu. Chińskie rodziny ogólnie wszystkie są takie. Jak pójdziesz do centrum handlowego lub do restauracji zjeść obiad, to zobaczysz głównie mamę prowadzącą jedno dziecko. Tak naprawdę one nie są samotnymi rodzicami, są tylko Chińczykami. Chińskich ojców nie obchodzą ich dzieci, nieważne, czy osiągną sukces w karierze, czy też nie. Możliwe, że ma to związek z ogólną praktyką w Chinach. Po drugie, chińscy mężczyźni nie mają cierpliwości. Uważam, że zajmowanie się dzieckiem wymaga ogromnej cierpliwości. Jest jeszcze jeden powód, drugi, ponieważ to matki rodzą dzieci, są przez 9 miesięcy w ciąży, a urodzenie dziecka jest bardzo bolesne. Tego wszystkiego ojcowie nie doświadczają, więc ich miłość w stosunku do dziecka w praktyce nie jest tak silna, jak miłość matek. Nie mają tyle miłości. Naprawdę tak uważam, że dzieci kochają oglądać ten film o szczęśliwej rodzinie, bo one bardzo pragną takiego życia. (Matka 5)

W kontekście tego, co powiedzieliśmy o kluczowej roli harmonii - notabene w nawiązaniu do wypowiedzi tej samej matki - widać wyraźnie pragnienie rozłożenia między dwojga rodziców zaangażowania w życie rodzinne. Kwestią kluczową jest nie tyle dostarczenie środków materialnych, ile samo uczucie, które jest tutaj potrzebne. Harmonia, o której mówi matka, jest według niej powiązana $\mathrm{z}$ byciem aktorem $\mathrm{w}$ roli ojca na poziomie tego samego zaangażowania, jakie przejawia matka. Widać tutaj wyraźnie odwołanie się do sytuacji współczesnej, która zmienia model rodziny chińskiej. Narracja bajki daje matce asumpt do skomentowania tej sytuacji i pokazania, jak sytuacja społeczna we współczesnych Chinach zagraża kultywacji tradycyjnych wartości. Symptomatyczne jest tutaj powiązanie harmonii społecznej (na poziomie rodziny) z możliwością dobrostanu rodzinnego i odczuwaniem szczęścia. Paradoksalnie ta matka, mówiąc o modelu zachodnim, tj. wspólnym wychowaniu dzieci przez oboje rodziców, inspiruje się oglądaną z dzieckiem bajką zachodnią, ale w rzeczy samej jednak wyraża raczej pragnienie zapisane w modelu chińskim. Marząc o szczęściu, marzy o powrocie do idei harmonii. O złączeniu tych dwóch idei mówi przywołany już wyżej tekst Po-Keung Ipa, który przypomina również, że już w latach 2006 i później, w oficjalnych dyrektywach wydawanych dla edukacji społecznej przez organa Partii Komunistycznej i przemówieniach oficjeli, podkreślano potrzebę powrotu do idei harmonii, tak jak jest ona zdefiniowana $\mathrm{u}$ Konfucjusza. Widać tutaj splot tego, co mówi matka w trakcie rozmowy o wychowawczej i wartościotwórczej roli bajek, ze współczesnymi przemianami, przed jakimi staje całe społeczeństwo chińskie, z jednoczesnym usytuowaniem tego wyzwania w kontekście własnej konfucjańskiej tradycji. 


\section{KONTRAST: BAJKI ZACHODNIE VERSUS BAJKI CHIŃSKIE}

Istotne jest także osobne odniesienie się do kwestii porównania bajek chińskich i zachodnich. Wypowiedzi matek potwierdzają, że jest to wartościowa platforma, która ujawnia kilka istotnych różnic między wschodnim i zachodnim modelem myślenia co do formy przekazywania kluczowych treści w utworach kultury popularnej, jakimi są współczesne bajki. W porównaniach, jakie podejmują matki w swoich wypowiedziach, ujawniają się dwa zasadnicze wątki $\mathrm{w}$ istotny sposób splatające się z sobą, a mianowicie forma przekazu oraz treści w nim zawarte.

Za punkt wyjścia weźmy trzy dłuższe wypowiedzi. Matka 6 mówi:

Uważam więc, że największa różnica między chińskimi i zagranicznymi materiałami do czytania jest taka, że chińskie bardzo lubią używać wielu słów do opisania jakiejśs sytuacji, a na koniec jeszcze rysują kwiatek i mówią: „Ta historia mówi nam to i to". Jak znowu dasz dziecku do przeczytania ten tekst, to w końcu po przeczytaniu około 3 minut dziecko już nie chce tego słuchać. Zagraniczne natomiast lubią używać wielu ilustracji i mało znaków [mało tekstu - A.G.], aby opisać jakąś sytuację, potem nie mówią ci, co odkrywają. [...]. Pozwalają ci mieć własne zdanie.

Ta sama Matka dodaje także w końcowym komentarzu:

Zagraniczne nie dają Ci stereotypowej odpowiedzi, ale pozwalają ci samemu powiedzieć, co jest dobre. To, co ty mówisz, jest dobre; to, co on mówi, też jest dobre. Według mnie to, co mówisz, jest bardzo dobre. Po prostu zagraniczne pozwalają ci mieć swoja własną opinię, co jest bardzo słuszne.

Matka 3, idąc tym samym tropem, mówi:

Wszystkie zagraniczne filmy mają szczególnie jasno sprecyzowany temat, np. przygoda, odwaga, wytrwałość, tego jest całkiem sporo. Krajowe filmy (chińskie) też mają, niektóre są zabawne, ale główny temat jest raczej kiepsko sprecyzowany.

Posiłkując się przytoczonymi i innymi wypowiedziami, spróbujmy najpierw połączyć styl przekazywania treści z tym, jakie to są treści, oraz jak badane matki ujmują potencjalnie oddziaływanie tych treści, wątków tematycznych na dzieci. Matki podkreślają, że chińskie bajki są mniej sprecyzowane, zakreślają naraz zbyt wiele wątków. Matka 4 podkreśla, że treści przekazywane przez bajki zagraniczne są ukazywane bardziej „bezpośrednio”, natomiast - jak zauważa - w bajkach chińskich treści są bardziej „rozmyte". Dalej podkreśla, że w chińskich bajkach szczególną uwagę zwraca się na 
„kontakty międzyludzkie” i „atmosferę między ludźmi”, czyli na otoczenie, w jakim ktoś funkcjonuje. Jednocześnie np. Matka 7 podkreśla, że bajki zagraniczne są jakby mniej „dziecinne”, dają jedną rzecz, wskazówkę, którą trzeba przemyśleć. Matka 8 podkreśla, że te różnice w stylu i formie przekazu, ale także w treści (do czego jeszcze wrócimy), mają swoje źródło w tym, że bajki chińskie ,pochodzą z tradycyjnych legend, a niektóre z historii z niezbyt odległych czasów". Matka 8 dodaje przy tym, co podkreślały także pozostałe kobiety, że w bajkach zagranicznych „wątek jest raczej prosty”.

Jak to należy rozmieć? Wskazówkę daje wypowiedź Matki 3, która w nawiązaniu do kilku bajek zachodnich (o Vaianie czy Królowej Lodu), podkreśla, że sprecyzowany temat, o którym mówią bajki zachodnie, to np. odwaga czy wytrwałość. Z kolei Matka 4 podkreśla, że bajki zachodnie zachęcają do pracy nad sobą, a Matka 7 mówi, że bajki zachodnie wskazują na świadomość wewnętrzną bohaterów.

Wydaje się, że matki proszone o zestawienie bajek zachodnich z bajkami chińskimi wychwytują kluczowe parametry kulturowe. Trzy kwestie w przytoczonym wyżej wypowiedziach wybijają się na plan pierwszy. Mówiąc o cechach wewnętrznych, takich jak odwaga itd., obecnych w bajkach zachodnich, a jednocześnie zwracając uwagę na obecność planu społecznego i historycznego w bajkach chińskich, matki odnoszą się pośrednio do obecnego w kulturze zachodniej indywidualizmu, polegającego - przypomnijmy - na tym, że kluczowe dla osoby są raczej cechy wewnętrzne, do nich się odnosimy w pierwszej kolejności, gdy jesteśmy pytani kim jesteśmy (Markus i Kitayama; Mesquita i Leu; Gut i Wilczewski). Jak pokazują z kolei badania przeprowadzane w kulturze Wschodu, pierwsza reflleksja na pytanie, kim jesteś, aktywuje raczej myślenie o byciu członkiem określonej grupy (np. bycie córką, bycie studentem itd.) (Bond). To wiąże się także z tym, że w tradycji chińskiej, co znowu pokazują liczne badania, zwraca się w percepcji lub myśleniu bardziej uwagę na tło. Obiekt, który się widzi lub o którym się myśli, jest zawsze ujmowany w powiązaniu z tłem. Do pewnego stopnia jest to ogólna zasada poznawcza, niemniej udział (wkład) tego, jakie jest tło, jest bardziej kluczowy w kulturze chińskiej niż zachodniej (Nisbett i Norenzayan). Koncentracja na cechach wewnętrznych bohatera bajki i skupienie się na centralnej postaci, a nie na tle, pozwala utrzymać bezpośredni charakter narracji, opowieści, o czym także mówią matki. Następnie, matki podkreślały, że ich zdaniem bajki zachodnie mają w sobie potencjał do uczenia dzieci do wyrażania swojego zdania. Moglibyśmy dodać: ekspresji osobistej. Matka $4 \mathrm{w}$ tym kontekście mówi, że bajki 
zagraniczne zachęcają do większej pracy nad sobą. Z wypowiedzi można wywnioskować, że w jakimś sensie w bajkach zachodnich pojawia się model do budowania motywacji wewnętrznej. Znowu z licznych badań wiadomo, że w społeczeństwie Chin, zgodnie $\mathrm{z}$ tradycją tamtej kultury, motywacja wewnętrzna jest ściśle powiązana $\mathrm{z}$ obowiązkami i rolą społeczną (Heine). Dobro innych, niechęć do zawiedzenia np. rodziców lub całej społeczności odgrywa przy tym kluczową rolę (Gut, Zhang i Ruszer).

Interesujące jest to, że matki, opowiadając o różnicach w wartościach, treściach $\mathrm{i}$ formie prezentowania bohaterów w bajkach zachodnich i chińskich, przywołują cały zespół wyżej wspomnianych i wyliczonych wskaźników. Nietrudno dostrzec, że to porównanie odbywa się na osi indywidualizm-kolektywizm czy też na osi ja niezależne i ja współzależne. Odpowiedzi matek formułowane na kanwie oglądanych $\mathrm{z}$ dziećmi bajek potwierdzają, jak wciąż głęboko zakorzenione w tradycji chińskiej jest myślenie, w którym zasadniczym wątkiem jest mocno skontekstualizowana narracja historyczna.

Trzeba pamiętać, że w ramach nowej polityki i wytycznych istnieje tendencja do ograniczania publikacji zachodnich (Leng). Tylko w 2017 r. wydano czterdzieści tysięcy książek dla dzieci. Segment literatury dziecięcej jest bardzo dochodowy, a tłumaczenia zachodnich książek stanowią niemały jego procent. Na chińskiej stronie z zakupami online JD.com trzy najlepiej sprzedające się książki z obrazkami to thumaczenia zagranicznych publikacji: seria „LesP'TitesPoules” francuskiego autora Christiana Jolibois, „Barefoot Books World Atlas" brytyjskiego pisarza Nicka Crane'a i ilustratora Davida Deana oraz zestaw książek o śwince Peppie, również z Wielkiej Brytanii. Od 2018 r. rząd określił dopuszczalną liczbę wydawanych zagranicznych książek, chcąc $\mathrm{w}$ ten sposób propagować chińską kulturę i wartości.

\section{PODSUMOWANIE}

Z powyższych rozważań wynika, jak wielowymiarowym materiałem do analiz okazały się wypowiedzi matek oraz jak pytania dotyczące oglądanych przez ich dzieci bajek dały asumpt do refleksji nad formami przekazu w bajkach, obecnymi tam wartościami i postawami. Jednocześnie w tych osobistych wypowiedziach ujawniły się wspólne dla wszystkich matek punkty odniesienia, wokół których ogniskowały się ich komentarze oraz refleksje. Interesujące jest to, że wszystkie matki w pierwszej kolejności 
(zob. tabela 1) wychwytywały negatywne wzorce obecne w bajkach. Dostrzegały wszechobecność przemocy, siły i agresji - szczególnie w bajkach chińskich, piętnując to zjawisko w swoich wypowiedziach. Strategia narracyjna matek i przeprowadzona analiza kategorialna ukazuje zatem, że matki w pierwszej kolejności skupiają się na tym, co budzi ich sprzeciw, i typach zachowań, jakie odrzucają. W tym sensie zasadniczą strategią wychowawczą w pierwszej kolejności jest ochrona własnych dzieci przed czymś, co budzi sprzeciw matki. W tym kontekście widać również rozziew między ideałami, które matki pragną przekazać własnym dzieciom, a tym, co istnieje w przestrzeni dziecięcej popkultury skierowanej do dzieci w Chinach. Matki mówią również o zderzeniu tradycji ze współczesnością szczególnie w kontraście przekazu, formy, treści i wzorców w bajkach chińskich i zachodnich. Niewątpliwie w tych wzorcach i wartościach, które matki doceniają w bajkach, widać wyraźne sygnały przemian w mentalności oraz świadomości matek jako pierwszych nauczycielek własnych dzieci. Matki doceniają budowanie w dzieciach motywacji wewnętrznej, chcą, aby ich dzieci nabywały zdolności do wyrażania własnego zdania, wyrobienia w sobie postawy krytycznej. Doceniają posiadanie przez dzieci horyzontu wiedzy, która obejmuje także znajomość innych kultur, ras, języków. Widać też przemianę, można nawet powiedzieć nowe trendy rzadko obecne w medialnej przestrzeni edukacyjnej w Chinach jeszcze kilkanaście lat temu. Matki często doceniają uczenie i wychowywanie dzieci w postawie proekologicznej, mówią, że podoba im się obecność w bajkach wątków dbania o przyrodę i środowisko. Jednocześnie $\mathrm{w}$ swoich narracjach matki ujawniają obecną u nich kulturowo zdefiniowany układ perspektyw, z jakich dokonują refleksji. W ich systemie refleksji można dostrzec wyraźną świadomość tradycji i wzorców chińskich, co pozwala im precyzyjnie wychwytywać wzorce obce - przyjmowane z zewnątrz - i konfrontować je z wzorcami chińskimi. W swoich refleksjach matki zbudowały - co było bardzo instruktywne - logiczny związek między formą, językiem, kontekstem historycznym obecnym w bajkach a przekazywanymi przez nie wartościami, postawami i wzorcami.

Na koniec, szczególnie w kontekście dyskursu nad harmonią w punkcie 6 i fenomenem bajki „Świnka Peppa” oraz docenianiem wzorców i bajek zachodnich, warto podkreślić, że bajka „Świnka Peppa” stała się bardzo popularna w Chinach i wręcz zawładnęła kulturą masową. Wizerunek świnki zaczął zdobić ubrania i zegarki, powstało bardzo wiele gadżetów ze Świnką Peppą (m.in. skarbonki, breloczki, torebki itp.). Wizerunek Peppy pojawia się również jako prawdziwy lub fałszywy tatuaż. Świnka Peppa stała się 
również bohaterką memów. Zagrała w reklamie, powstał także długometrażowy film o Śwince Peppie pt. „Peppa Pig: Festival of Fun”. W 2018 r. jednak władze chińskie zakazały emisji tej bajki pod zarzutem, że propaguje ona wartości „gangsterskie” („China bans Peppa”). Bajka zniknęła z kanału Douyin, na którym była wyświetlana od 2015 r. Świnka Peppa stała się symbolem kontrkultury, społeczności określanej mianem Shehui ren 社会人.

\section{BIBLIOGRAFIA}

Afek, Joanna, i Arkadiusz Gut. „O chińskim modelu wczesnej edukacji dziecięcej w kontekście międzykulturowych badań psychologicznych”. Roczniki Humanistyczne, vol. 65, z. 9, 2017, ss. 5-28, doi: 10.18290/rh.2017.65.9-1.

Becky, Francis, i Louise Archer. „British-Chinese pupils' and parents' constructions of the value of education". British Educational Research Journal, vol. 31, no.1, 2005, ss. 89-108, doi: 10.1080/0141192052000310047.

Bettelheim, Bruno. Cudowne i pożyteczne. O znaczeniach i wartościach baśni. T. 1-2. Przeł. Danuta Danek. Państwowy Instytut Wydawniczy, 1985.

Bond, Michael Harris. „Chinese values”. Handbook of Chinese psychology, red. Michael Harris Bond, Oxford University Press, 1996, ss. 208-226.

Chao, Ruth K. „Beyond parental control and authoritarian parenting style: Understanding Chinese parenting thought cultural notion of training". Child Development, vol. 65, no. 4, 1994, ss. 1111-1119, doi: 10.2307/1131308.

„China bans Peppa Pig because she "promotes gangster attitudes””. Independent, 3 maja 2018 www.independent.co.uk/news/world/asia/peppa-pig-ban-china-childrens-tv-cartoon-gangsterdouyin-a8332846.html. Dostęp 12.12.2019.

Choy, Grace. „Chinese Culture in Early Educational Environment”. Early Childhood Education in Chinese Societies, red. Nirmala Rao, Jing Zhou i Jin Sun, Springer, 2017, ss. 31-54.

Chua, Amy L. Bojowa pieśń tygrysicy. Dlaczego chińskie matki sq najlepsze? Przeł. Magdalena Moltzan-Małkowska, Prószyński i S-ka, 2011.

Chuang, Susan S., i Yanjie Su. „Do We See Eye to Eye? Chinese Mothers' and Fathers' Parenting Beliefs and Values for Toddlers in Canada and China”. Journal of Family Psychology, vol. 23, no. 3, 2009, ss. 331-341, doi: 10.1037/a0016015.

Early Childhood Education in Chinese Societes, red. Nirmala Rao, Jing Zhou, Jin Sun, Springer Science + Business Media, 2017.

Eisfeld, Conny. How Fairy Tales live happily ever after: (Analyzing) The art of adapting Fairy Tales. Anchor Academic Publishing, 2015.

Exploring the child's personality: Clinical and cross-cultural applications of the Fairy Tale Test red. Carina Coulacoglou, C.C. Thomas, 2008.

Falbo, Toni. „Evaluations of the behavioral attributes of only children in Beijing, China: moderating effects of gender and the one-child policy". Heliyon vol. 4, no. 4, e00607, 2018, doi: 10.1016/ j.heliyon.2018.e00607. 
Fung, Heidi. „Becoming a Moral Child: The Socialization of Shame among Young Chinese Children”. Ethos, vol. 27, no. 2, 1999, ss. 180-209, doi: 10.1525/eth.1999.27.2.180.

Gallas, Karen. The Languages of Learning: How Children Talk, Write, Dance, Draw, and Sing Their Understanding of the World. Teachers College Press, 1994.

Gut, Arkadiusz. „Kulturowo-językowe uwikłanie atrybucji społecznych w obszarze moralności i epistemologii”. Spotkania Polonistyk Trzech Krajów - Chiny, Korea, Japonia. Rocznik 2016/2017. Międzynarodowa Konferencja Akademicka w Kantonie, red. Mao Yinhui, Wydawnictwo Naukowe Sub Lupa, 2018.

Gut, Arkadiusz, i Joanna Afek. Recenzja książki: Nirmala Rao, Jing zhou, Jin Sun (eds.), Early Childhood Education in Chinese Societes, seria „International Perspectives on Early Childhood Education and Development", Springer Science + Business Media. Psychologia Rozwojowa, vol 23, nr 4, 2018, ss. 111-115.

Gut, Arkadiusz, Zhao Gang i Andrzej Ruszer. „Kulturowe czytanie literatury. Społeczne parametry ewaluacji bohatera literackiego (przypadek Wokulskiego)". Roczniki Humanistyczne, vol. 66, z. 9, 2018, ss. 161-195, doi: 10.18290/rh.2018.66.9-8.

Gut, Arkadiusz, i Michał Wilczewski. „Is mindreading universal or cultural specific construct?”. CEUR, 2015, ceur-ws.org/Vol-1419/paper0081.pdf, ss. 499-505.

Heine, Steven J. „Culture and Motivation: What Motivates People to Act in the Ways That They Do?". Handbook of Cultural Psychology, red. Shinobu Kitayama i Dov Cohen, The Guilford Press, 2007, ss. 714-733. .

Jones, Andrew F. . Developmental Fairy Tales: evolutionary thinking and modern Chinese culture. Harvard University Press , 2011.

Po-Keung Ip. „Harmony as Happiness? Social Harmony in Two Chinese Societies”. Social Indicators Research, vol. 117, no. 3, 2014, ss. 719-741, doi: 10.1007/s11205-013-0395-7.

Konfucjusz. Analekta. Tłum. i oprac. Katarzyna Pejda. Wydawnictwo Uniwersytetu Warszawskiego, 2018.

Leng, Sidney. „What does China have against Peppa Pig?” South China Morning Post, 20 lipca 2018, www.scmp.com/news/china/policies-politics/article/2077049/what-does-china-have-againstpeppa-pig. Dostęp 12.12.2019.

Li Yuhui, Zhang Jiannxin. „The Application of the Fairy Tale Test in China”. Exploring the child's personality: Clinical and cross-cultural applications of the Fairy Tale Test, red. Carina Coulacoglou, C.C. Thomas, 2008, ss. 219-242.

Markus, Hazel Rose, i Shinobu Kitayama. „Culture and the self: Implications for cognition, emotion, and motivation". Psychological Review, vol. 98, no. 2, 1991, ss. 224-253, doi: 10.1037/ 0033-295X.98.2.224.

McCabe, Allyssa, "Cultural background and storytelling: A review and implications for schooling". The Elementary School Journal, vol. 97, no. 5, 1997, ss. 453-473, doi: 10.1086/461876.

Mesquita, Batja, i Janxin Leu. „The Cultural Psychology of Emotion”. Handbook of Cultural Psychology, red. Shinobu Kitayama i Dov Cohen, The Guilford Press, 2007, ss. 734-759.

Nisbett, Richard E., i Ara Norenzayan. „Culture and cognition”. Stevens' Handbook of Experimental Psychology. 3rd edition, red. Douglas Medin i Hal Pashler, John Wiley \& Sons, 2002.

Preda, Vasile, i Elena Cocorada. „The Therapeutic Use of the Romanian Fairytales in Improving the Patent-Child Relationship and Wellbeing". Romanian Journal of Experimental Applied Psychology. vol. 8, special issue, 2017, ss. 337-342, doi:10.15303/rjeap.2017.si1.a54. 
Sanyal, Nilanjana, i Manisha Dasgupta. „Fairy tales: The Emotional Processors of Childhood Conflicts in Dynamic Interpretative Lens". SIS Journal of Projective Psychology \& Mental Health, vol. 24, no. 1, 2017, ss. 39-47.

Seok, Bongrae. Embodied Moral Psychologyand Confucian Philosophy. Lexington Books, 2013.

Xiao, Zhang. „The Effects of Parental Education and Family Income on Mother - Child Relationships, Father - Child Relationships, and Family Environments in the People's Republic of China”. Family Process, vol. 51, no. 4, 2012, ss. 483-497.

Zhang, Yehong, i Gerhard Lauer. „How Culture Shapes the Reading of fairy Tales: a Cross-Cultural Approach". Comparative Literature Studies, vol. 52, no. 4, 2015, ss. 663-681.

Zipes, Jack. Fairy Tale as Myth, Myth as Fairy Tale. University of Kentucky Press, 1994.

\section{REFLEKSJE MATEK CHIŃSKICH NAD SYSTEMEM WARTOŚCI I WZORCÓW SPOŁECZNYCH ZAWARTYCH W BAJKACH: KULTUROWA ANALIZA NARRACYJNA}

Streszczenie

W artykule zostaje podjęta próba odkrycia kulturowo określonych i indywidualnych punktów widzenia dotyczących edukacji dzieci w Chinach. Artykuł opiera się na badaniach przeprowadzonych Pekinie. Osobami badanymi były matki, które zostały poproszone o zaprezentowanie w formule narracyjnej swoich poglądów na temat oglądanych i czytanych przez ich dzieci baśni i bajek. Rozmówczynie były proszone również o ocenę w różnych aspektach przekazu, treści, wartości, ideałów i postaw przekazywanych przez bajki chińskie i zachodnie. Jednocześnie opowiadały, jak oglądane i czytane treści oraz formy przekazu wpisują się w ich oczekiwania, strategie związane z wychowaniem dzieci. Otrzymany dzięki temu bogaty materiał do analizy kulturowej pozwolił Autorom zestawić listę bajek chińskich oraz zachodnich oglądanych przez dzieci chińskie, dowiedzieć się, jakie wartości i postawy w opinii matek przekazują wymieniane bajki, a następnie, zobaczyć, jak matki porównują zachodnie i chińskie bajki w odniesieniu do tych postaw i wartości, które chcą zaszczepiać swoim dzieciom. W analizie eksploracyjnej i kategorialnej udało się wyróżnić główne kategorie, na które rozmówczynie zwracają uwagę, oraz ukazać wymiary kulturowe, w jakich matki zestawiają i porównują przekaz zawarty w bajkach chińskich i zachodnich.

Słowa kluczowe: bajki; dziecko; metody wychowawcze; narracje; matki chińskie; wartości kulturowe; Chiny. 